ORIGINAL ARTICLE

\title{
Deviated nasal septum and nasal polyps in COVID-19 patients: A case control study in DHQ Teaching Hospital, Mirpur, Azad Jammu and Kashmir Pakistan.
}

\author{
Sidra Aslam', Muhammad Kaleem², M Aurang Zeb³, Ejaz Ahmed ${ }^{4}$, Syed Manzoor lqbal', Faisal Bashir
}

Article Citation: Aslam S, Kaleem M, Aurang Zeb M, Ahmed E, Iqbal SM, Bashir F. Deviated nasal septum and nasal polyps in COVID-19 patients: A case control study in DHQ teaching hospital, Mirpur, Azad Jammu and Kashmir Pakistan. Professional Med J 2022; 29(3):389394. https://doi.org/10.29309/TPMJ/2022.29.03.6189

ABSTRACT... Objective: To correlate the prevalence of COVID-19 and the rhinopathological conditions simultaneously in the population visiting the hospital of Mirpur, Azad Jammu and Kashmir. Study Design: Case-control study. Setting: District Head Quarter (DHQ) Teaching Hospital Located in Mirpur, Azad Jammu and Kashmir. Period: September 2020 to February 2021. Material \& Methods: Patients visiting the DHQ teaching hospital, Mirpur, Azad Jammu and Kashmir for their COVID-19 related symptoms were included in the study. Demographic data was obtained. Prevalence of DNS and nasal polyps was recorded for further statistical analysis of the symptoms in the population. The obtained patient data was evaluated for the rhinopathological conditions that exists with the prevailing COVID-19 or may even aggravate the situation. Although nasal polyps and DNS are not among the typical symptoms of the COVID-19 but they may add to the results of PCR testing following swab testing. Conclusion: Despite being a significant relationship, there lies a chance of misleading results of swab testing as these rhinopathies obstruct the airway hindering the path. Therefore, while carrying out a confirmation test for the infection it is important to consider the chances of rhinopathies in patients beforehand.

Key words: $\quad$ Coronavirus, COVID-19, Case-Control Study, Deviated Nasal Septum, Nasal Polyps.

\section{INTRODUCTION}

Severe acute respiratory syndrome also termed as coronavirus 2 (SARS-CoV-2) has become a major health concern globally. Since the beginning of this year, the number of infections and deaths reported every day around the world has been increasing. This led to an increased focus towards the pandemic emerged by SARSCoV-2, a $\beta$-coronavirus associated to SARS-CoV. Some of the common symptoms associated with COVID-19 include cough, fever, dyspnea, myalgia, malaise, and gastrointestinal diseases. ${ }^{1}$ Furthermore, COVID-19 patients have also reported complaints of olfactory dysfunction (OD) oranosmia. ${ }^{2}$ Previously, mostresearches exploring OD in COVID-19 utilized various retrospective questionnaires or the symptoms reported by patients themselves. ${ }^{3}$ These evaluation methods are prone to reporting bias and may not be able to identify subtle ODs. Therefore, it is necessary to objectively measure COVID-19 patients' olfactory functions. Additionally, no comparison of olfactory functioning in COVID-19 has been done previously with the healthy controls. It is a necessary condition proving that these patients have impaired sense of smell. There is also a lack of systematic assessment of the etiology, prevalence, severity along with the duration of OD in patients with COVID-19. ${ }^{4}$

Nasal obstruction is one of the most common complaints faced by otolaryngologists in daily practice. The most common cause of nasal congestion is the deviation of the nasal septum. It can lead to changes in air flow dynamics, and multiple histopathological changes in the nasal mucosa are also observed. Deviated nasal septum (DNS) is the most common cause of nasal congestion. It causes snoring, breathing through mouth and deformities in the external
1. MBBS, M.Phil (Pathology), Senior Lecturer Pathology, DHQ-TH Mirpur AJK.

2. MBBS, M.Phil (Pathology), Assistant Professor Pathology, DHQ-TH Mirpur AJK

3. MBBS, FCPS (Pathology), Pathologist, CMH Bahawalpur.

4. MBBS, FCPS, Assistant Professor ENT, DHQ-TH Mirpur AJK.

5. MBBS, M.Phil (Pathology), Professor Pathology, DHQ-TH Mirpur AJK.

6. MBBS, DLO, FCPS, Associate Professor ENT, Mirpur AJK.
Correspondence Address:
Dr. Muhammad Kaleem
Department of Pathology
DHQ-TH Mirpur AJK.
kaleem_ch724@hotmail.com

Article received on:

$07 / 11 / 2020$ $16 / 08 / 2021$ 
nasal areas. The airflow dynamics of the nasal cavity is also affected and improper ventilation of the paranasal sinuses also occur causing sinusitis. The changes in airflow, compensatory hypertrophy of the concave mucosa of the nose is also observed. ${ }^{5}$ Multiple variations caused by changes in airflow dynamics are mucociliary dysfunction, infiltration of lymphocyte and metaplasia of squamous cells. There is clear visibility of these changes on the either side of the nasal mucosa, the severity is much observed on the concave side. ${ }^{6}$ Correcting the DNS surgically can avoid all these changes. The deviation of the nasal septum may impart various symptoms including nasal congestion, breathing through mouth, and other indications such as headaches and the olfactory disturbances. The nasal cavity's dynamic airflow is also affected by the position, degree, and the shape of the deflection in nasal septum.

Chronic sinusitis with nasal polyps (CRSwNP) is considered clinically important as and can be diagnosed by subjectively and objectively evident from the chronic sinusitis. ${ }^{7}$ Rhinorrhea at the anterior and posterior of the nose, congestion in the nasal cavity, hypotonicity along with pressure on the face with lasting more than 12 weeks are some of the common symptoms observed. The inflammatory lesions extending in the airway passage of the nose, typically bilateral originating from the ethmoid sinusis termed as nasal polyps. The susceptibility is observed in men more than the women, however, there is no evidence of environmental factor contributing to the occurrence of disease. Allergic rhinitis and asthma are usually closely related to CRSwN However, multiple cellular and molecule based mechanisms may develop such symptoms that are still under consideration. ${ }^{8}$

The diagnosis for infection of COVID-19 may be done via fluids collected from the respiratory tracts (upper and lower) involving the oropharynx (OP), sputum from the nasopharynx (NP), and through the fluids from bronchus. ${ }^{9}$ Generally, COVID-19 can be detected most sensitively through the samples obtained from the upper and lower respiratory tract. ${ }^{10}$ Bronchoscopy, however, is much advanced procedure involving technological difficulties and sophisticated diagnostic tools with sufficiently trained staff. In addition, sputum collection through bronchoscopy, especially BAL, may increase the risk of biosafety of medical staff by generating aerosol droplets. The collection of specimens of the upper respiratory (OP and NP swabs) is comparatively easy specifically with the limited resources.Such specimens may be obtained in the initial days when the symptoms are observed, because the positive RNA rate peaks in these samples seven to ten days after the starting of symptoms, and then graduallydeclines. The correct collection of nasopharyngeal swabs that reach the area of the posterior nasopharyngeal tonsil seems very important. ${ }^{11}$ This means that there is a regular bottom of the nasal cavity. Some anatomical changes, may prevent appropriate sample collection such as a deflection of the nasal septum. Numerous studies of nasal septum deflection have shown its widespread prevalence. In a study, it was found that the prevalence is about $90 \%$ in adults. It is also reported a relevant interval deviation with a prevalence of 15 to 25 percent. ${ }^{12}$ Hence, keeping in view the prevailing pathological conditions, a definite diagnosis is a matter of concern.

\section{OBJECTIVES}

- To associate nasal pathological conditions with the prevalence of COVID-19 in Mirpur, Azad Jammu and Kashmir.

- To affirm the relationship of proper diagnosis of a positive COVID-19 case with symptomatic patients.

Rhinopathological conditions may alter or obstruct the airway passages hence making the test for COVID-19 by swab difficult and unapproachable. The following study aimed to correlate the prevalence of COVID-19 and the rhinopathological conditions simultaneously in the population visiting the hospital of Mirpur, Azad Jammu and Kashmir. This could help the health care practitioners in designing different identification methods for COVID-19, keeping in view the difficulty of swab tests. 


\section{MATERIAL \& METHODS}

The following study was conducted in order to evaluate the prevalence of COVID-19 in the people of Mirpur, Azad Jammu and Kashmir particularly focusing on the symptoms that are observed during the illness. Nasal polyps and DNS along with SARS-CoV-2, was highlighted among the patients having positive and negative tests for COVID-19. The age of the patients was also considered to correlate the effect of illness on the patients of different age groups.

A cross sectional study was conducted from September 2020 to February 2021 in the locality of Mirpur, Azad Jammu and Kashmir, Pakistan. Division Head Quarter (DHQ) teaching hospital, Mirpur was targeted and the influx of patients with COVID-19 symptoms were monitored. For the confirmation of the disease, PCR testing was carried out in PCR Lab Microbiology Division Department of Pathology DHQ Teaching Hospital Mirpur, Azad Jammu and Kashmir. Sampling was done by microbiology department whereas examination was made by ENT department of the hospital. The study was conducted after acquiring an approval from the ethical board of the committee (DHQ Teaching Hospital Mirpur, AJK vide Reference No.17155) Frequency distribution of the demographics were calculated. T-test was applied for the calculation of p-values using statistical software such as IBM SPSS Statistics 25.

\section{RESULTS}

Demographics of patients with COVID-19 symptoms.

\begin{tabular}{|c|c|c|c|c|}
\hline & \multicolumn{2}{|c|}{ Gender of Patients } & \multirow{3}{*}{$\begin{array}{c}\text { Total } \\
7\end{array}$} \\
\hline & & Male & Female & \\
\hline \multirow{6}{*}{$\begin{array}{l}\text { Age of } \\
\text { Patients }\end{array}$} & $<15$ & 1 & 6 & \\
\hline & $15-30$ & 59 & 21 & 80 \\
\hline & $30-45$ & 76 & 23 & 99 \\
\hline & $45-60$ & 33 & 8 & 41 \\
\hline & $60-75$ & 12 & 2 & 14 \\
\hline & $>75$ & 1 & 3 & 4 \\
\hline \multicolumn{2}{|l|}{ Total } & 182 & 63 & 245 \\
\hline
\end{tabular}

Table-I. Demographics of patients participated in the study.
Among the patients visiting the hospital, it was observed that $28.8 \%$ had a presentation of DNS while the rest $71.2 \%$ were presented without physical symptoms of DNS. The distribution if depicted in figure below.

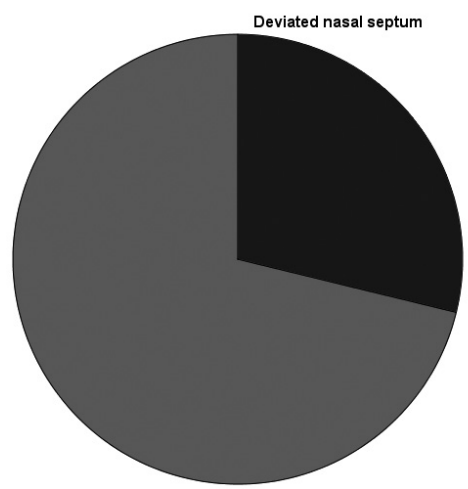

$\mathbf{B}_{\mathrm{n}}^{\mathrm{res}}$

Figure-1. Frequency distribution of patients with DNS.

Among the patients of Mirpur, Azad Jammu and Kashmir, 2.4\% were presented with nasal polyps while the rest $97.6 \%$ were without any indication.

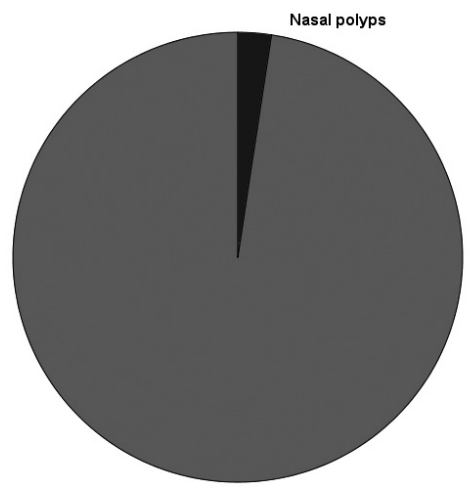

$\underset{\substack{\mathrm{r} \\ \mathrm{M}}}{\mathrm{res}}$

Figure-2. Frequency distribution of patients with nasal polyps.

Correlation of prevailing condition of DNS with COVID-19.

\begin{tabular}{|l|l|c|c|c|c|}
\hline & \multicolumn{3}{|c|}{$\begin{array}{c}\text { Deviated } \\
\text { Nasal } \\
\text { Septum }\end{array}$} & Total & P-Value \\
\hline & Yes & No & & \\
\hline $\begin{array}{l}\text { Remarks of PCR } \\
\text { test for COVID-19 }\end{array}$ & Positive & 12 & 25 & 37 & 0.002541 \\
\cline { 2 - 6 } & Repeat & 2 & 0 & 2 & 0.292893 \\
\hline Total & 72 & 178 & 250 & \\
\hline
\end{tabular}

Table-II. Relationship between the DNS prevalence with PCR test results of COVID-19. 


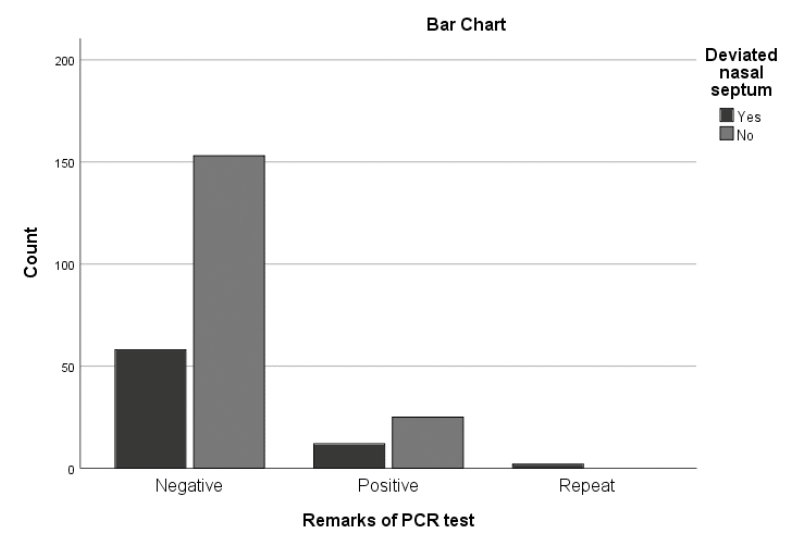

Figure-3. Relationship between the DNS prevalence with PCR test results of COVID-19.

Correlation of prevailing condition of nasal polyps with COVID-19

\begin{tabular}{|c|c|c|c|c|c|c|}
\hline \multicolumn{2}{|c|}{} & \multicolumn{3}{c}{ Nasal Polyps } & Total & P-Value \\
\hline & Yes & No & & \\
\hline $\begin{array}{c}\text { Remarks of } \\
\text { PCR test for } \\
\text { COVID-19 }\end{array}$ & Negative & 0 & 211 & 211 & 0.0000055 \\
\cline { 2 - 6 } & Resitive & 6 & 31 & 37 & 0.0008669 \\
\hline Total & & 6 & 2 & 2 & 0.2928932 \\
\hline
\end{tabular}

Table-III. Relationship between the nasal polyps' prevalence with PCR test results of COVID-19.

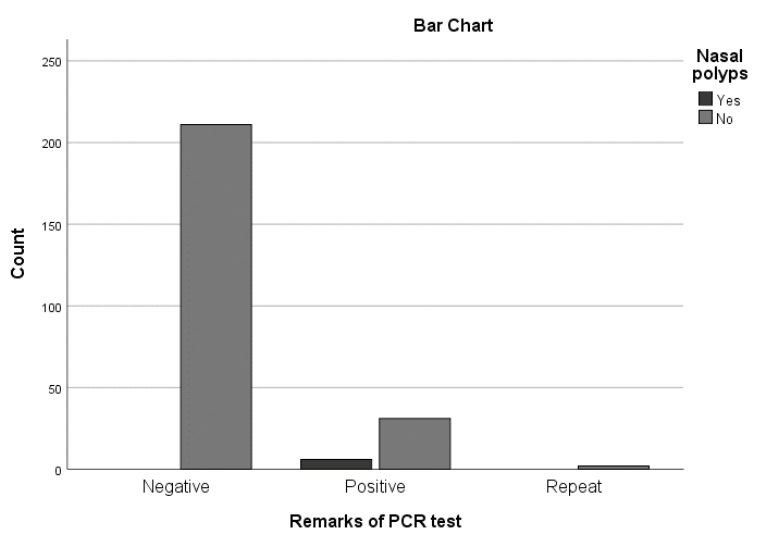

Figure-4. Relationship between the nasal polyps' prevalence with PCR test results of COVID-19.

\section{DISCUSSION}

The following investigation was carried out to consider the existing relationship among rhino pathological conditions and their effects in the development, progress and testing of serious infections such as COVID-19. It was observed from the study that only 12 of a total 250 patients had DNS along with a positive COVID-19 test.
While for the rest either the test was negative or the prevalence of DNS was not existing. Similarly, for nasal polyps, it was found that 6 of the total patients (250) were suffering from both the conditions of COVID-19 as well as developed nasal polyps while the rest did not have these symptoms. The results suggested no significant correlation between the already existing pathological conditions of the rhinus and progression of COVID-19. However, in some studies a justifiable mechanism is presented to correlate the two.

The SARS-CoV receptor ACE2 is used by the virus to enter cells, and uses serine protease TMPRSS2 for $S$ protein priming. ${ }^{13}$ According to reports, the expression of ACE2 in the nasal cavity is higher than that in the throat tissue. In fact, compared to throat swabs obtained from patients having the COVID-19, a higher SARS-CoV-2 viral load was detected in the nose, which is attributed to the ACE2 between the two tissues. ${ }^{14} \mathrm{~A}$ higher SARS CoV-2 viral load was detected in the nose when the swabs obtained from the COVID infected patients was observed. The difference in the ACE2 expression could be an important reason behind this. ${ }^{15}$ Recently, in a study that compared with the lower respiratory tract, the upper respiratory tract highly expresses the virus into two different genes TMPRSS2 and ACE2. ${ }^{16}$ In a recent study, it was observed that theACE2 is usually expressed by the multiciliated cells in nasal tissues and causes the disease. ${ }^{17}$ In addition, in another study, while analyzing the human nasal epithelium via singlecell RNA sequencing demonstrated that both of these genes are co-expressed by the innate immunity of the host in the nasal epithelium. ${ }^{18,19}$ SARS CoV-2 infection can be caused by these genes and the levels of the virus in the nasal tissues may correlate to the infectivity level of the virus.

We must urgently understand about the virus, the way it spreads infections so rapidly around the world, the pathogenic mechanism related to the entry of virus in the cells and spread of infection in the humans, the continuous transmission in the body, along with the difference determining factors among them both. The fatality and 
severity of infection may also vary between two people. The age and health along with other comorbidities in different population groups may also affect the severity of the disease spread and hence, the appropriate treatment is necessary to be developed. On the one hand, we may require social isolation and the use of face masks, while on theother hand, we also need to be vaccinated. ${ }^{20}$

Understanding how this virus successfully infects an individual and first enters the outer surface cells and begins to replicate is critical, as this may provide a treatment prospectively. The entrance of the virus is generally by the nose and nasopharyngeal region. A study determining the viral load in the patients demonstrated a higher concentration in the nose as compare to the throat. ${ }^{21}$ In addition, the world has learnt painful lessons from many healthcare specialists (especially otolaryngology) and ENT where the expert died of COVID-19. ${ }^{22}$

Both the national and the international guidelines currently available does not provide any specific measures for nasopharyngeal swabs for patients with rhinopathy records or those with bilateral nasal fossa disorders. It is believed however, that the support of otolaryngology must be obtained to gather the sample. In addition, endoscopy may turn out to be useful in direct visualization o the hinderance while taking the sample through the swab from the nasopharynx. This may also decrease the incorrect alarm rate that may be reported to be more than $30 \% 23$.

\section{CONCLUSION}

The present study was conducted in order to develop a relationship between COVID-19 and rhinopathies. Despite being a significant relationship, there lies a chance of misleading results of swab testing as these rhinopathies obstruct the airway hindering the path. Therefore, while carrying out a confirmation test for the infection it is important to consider the chances of rhinopathies in patients beforehand.

\section{Copyright@ 16 Aug, 2021.}

\section{REFERENCES}

1. Bilgin S, Kurtkulagi $O$, Kahveci GB, Duman TT, Tel BM. Millennium pandemic: A review of coronavirus disease (COVID-19). Experimental Biomedical Research. 2020 Mar 29; 3(2):117-25.

2. Chung TW, Sridhar S, Zhang AJ, Chan KH, Li HL, Wong FK, Ng MY, Tsang RK, Lee AC, Fan Z, Ho RS. Olfactory dysfunction in coronavirus disease 2019 patients: Observational cohort study and systematic review. In Open Forum Infectious Diseases 2020 Jun (Vol. 7, No. 6, p. ofaa199). US: Oxford University Press.

3. Bagheri $\mathrm{SH}$, Asghari $\mathrm{A}$, Farhadi $\mathrm{M}$, Shamshiri $\mathrm{AR}$, Kabir A, Kamrava SK, Jalessi M, Mohebbi A, Alizadeh R, Honarmand AA, Ghalehbaghi B. Coincidence of COVID-19 epidemic and olfactory dysfunction outbreak in Iran. Medical Journal of the Islamic Republic Of Iran. 2020; 34:62.

4. Lechien JR, Chiesa-Estomba CM, De Siati DR, Horoi M, Le Bon SD, Rodriguez A, Dequanter D, Blecic S, El Afia F, Distinguin L, Chekkoury-Idrissi Y. Olfactory and gustatory dysfunctions as a clinical presentation of mild-to-moderate forms of the coronavirus disease (COVID-19): A multicenter European study. European Archives of Oto-Rhino-Laryngology. 2020 Aug; 277(8):2251-61.

5. Higuera S, Lee El, Cole P, Hollier Jr LH, Stal S. Nasal trauma and the deviated nose. Plastic and reconstructive surgery. 2007 Dec 1; 120(7):64S-75S.

6. Reitzen SD, Chung W, Shah AR. Nasal septal deviation in the pediatric and adult populations. Ear, Nose \& Throat Journal. 2011 Mar; 90(3):112-5.

7. Förster-Ruhrmann U, Szczepek AJ, Bachert C, Olze $H$. COVID-19 in a patient with severe chronic rhinosinusitis with nasal polyps during therapy with dupilumab. Journal of Allergy and Clinical Immunology. 2020 Jul 1; 146(1):218-20.

8. Bleier BS, Welch KC. Preprocedural COVID $\square 19$ screening: Do rhinologic patients carry a unique risk burden for false $\square$ negative results? InInternational forum of allergy \& rhinology 2020 Jun 18.

9. Laidlaw TM, Mullol J, Fan C, Zhang D, Amin N, Khan A, Chao J, Mannent LP. Dupilumab improves nasal polyp burden and asthma control in patients with CRSwNP and AERD. The Journal of Allergy and Clinical Immunology: In Practice. 2019 Sep 1; 7(7):2462-5.

10. Chaaban MR, Walsh EM, Woodworth BA. Epidemiology and differential diagnosis of nasal polyps. American journal of rhinology \& allergy. 2013 Nov; 27(6):473-8. 
11. Vultaggio A, Agache I, Akdis CA, Akdis M, Bavbek S, Bossios A, Bousquet J, Boyman O, Chaker AM, Chan $S$, Chatzipetrou A. Considerations on biologicals for patients with allergic disease in times of the COVID $\square 19$ pandemic: an EAACI Statement. Allergy. 2020 Nov; 75(11):2764-74.

12. Settipane GA. Nasal polyps: Epidemiology, pathology, immunology, and treatment. American Journal of Rhinology. 1987 Sep; 1(3):119-26.

13. Hoffmann M, Kleine-Weber $H$, Schroeder S, Krüger N, Herrler T, Erichsen S, Schiergens TS, Herrler G, Wu $\mathrm{NH}$, Nitsche A, Müller MA. SARS-CoV-2 cell entry depends on ACE2 and TMPRSS2 and is blocked by a clinically proven protease inhibitor. cell. $2020 \mathrm{Apr}$ $16 ; 181(2): 271-80$.

14. Ziegler CG, Allon SJ, Nyquist SK, Mbano IM, Miao VN, Tzouanas CN, Cao Y, Yousif AS, Bals J, Hauser $\mathrm{BM}$, Feldman J. SARS-CoV-2 receptor ACE2 is an interferon-stimulated gene in human airway epithelial cells and is detected in specific cell subsets across tissues. Cell. 2020 Apr 27.

15. Chan JF, Zhang AJ, Yuan S, Poon VK, Chan CC, Lee AC, Chan WM, Fan Z, Tsoi HW, Wen L, Liang R. Simulation of the clinical and pathological manifestations of coronavirus disease 2019 (COVID-19) in a golden Syrian hamster model: Implications for disease pathogenesis and transmissibility. Clinical infectious diseases. 2020 Nov 1; 71(9):2428-46.

16. Lukassen S, Chua RL, Trefzer T, Kahn NC, Schneider MA, Muley T, Winter H, Meister M, Veith C, Boots AW, Hennig BP. SARS $\square$ CoV $\square 2$ receptor ACE 2 and TMPRSS 2 are primarily expressed in bronchial transient secretory cells. The EMBO journal. 2020 May 18; 39(10):e105114.
17. Hou Y, Zhao J, Martin W, Kallianpur A, Chung MK, Jehi L, Sharifi N, Erzurum S, Eng C, Cheng F. New insights into genetic susceptibility of COVID-19: An ACE2 and TMPRSS2 polymorphism analysis. BMC medicine. 2020 Dec; 18(1):1-8.

18. Chang ET, Adami HO. The enigmatic epidemiology of nasopharyngeal carcinoma. Cancer Epidemiology and Prevention Biomarkers. 2006 Oct 1; 15(10):176577.

19. Sungnak W, Huang N, Bécavin C, Berg M, Queen R, Litvinukova M, Talavera-López C, Maatz H, Reichart D, Sampaziotis F, Worlock KB. SARS-CoV-2 entry factors are highly expressed in nasal epithelial cells together with innate immune genes. Nature medicine. 2020 May; 26(5):681-7.

20. Wang LS, Wang YR, Ye DW, Liu QQ. A review of the 2019 Novel Coronavirus (COVID-19) based on current evidence. International journal of antimicrobial agents. 2020 Mar 19:105948.

21. Yu F, Yan L, Wang N, Yang S, Wang L, Tang Y, Gao G, Wang S, Ma C, Xie R, Wang F. Quantitative detection and viral load analysis of SARS-CoV-2 in infected patients. Clinical Infectious Diseases. 2020 Jul 28; 71(15):793-8.

22. Kowalski LP, Sanabria A, Ridge JA, Ng WT, de Bree R, Rinaldo A, Takes RP, Mäkitie AA, Carvalho $A L$, Bradford CR, Paleri V. COVID $\square 19$ pandemic: Effects and evidence $\square$ based recommendations for otolaryngology and head and neck surgery practice. Head \& neck. 2020 Jun; 42(6):1259-67.

23. Basso D, Aita A, Navaglia F, Franchin E, Fioretto P, Moz S, Bozzato D, Zambon CF, Martin B, Dal Prà C, Crisanti A. SARS-CoV-2 RNA identification in nasopharyngeal swabs: Issues in pre-analytics. Clinical Chemistry and Laboratory Medicine (CCLM). 2020 Jun 22; 1(ahead-of-print).

\begin{tabular}{|c|l|l|l|}
\hline \multicolumn{3}{|c|}{ AUTHORSHIP AND CONTRIBUTION DECLARATION } \\
\hline No. & \multicolumn{1}{|c|}{ Author(s) Full Name } & \multicolumn{1}{|c|}{ Contribution to the paper } & Author(s) Signature \\
\hline 1 & Sidra Aslam & $\begin{array}{l}\text { Direct/sample processing \& } \\
\text { diagnosis. } \\
\text { Direct / evaluation. }\end{array}$ \\
\hline 2 & Muhammad Kaleem & Intirect / sample processing. \\
\hline 4 & M Aurang Zeb & Intirect / sample processing. \\
\hline 5 & Syed Manzoor lqbal & $\begin{array}{l}\text { Indirect evaluation / literature } \\
\text { review. } \\
\text { Indirect literature review. }\end{array}$ \\
\hline
\end{tabular}

